\title{
ERRATA
}

Nonlinear Estimation of Monod Growth Kinetic Parameters from a Single Substrate Depletion Curve

\author{
JOSEPH A. ROBINSON AND JAMES M. TIEDJE
}

Department of Microbiology and Public Health, Michigan State University, East Lansing, Michigan 48824

Volume 45 , no. 5, p. 1454 , column 1, line 26 : "dS/d $\mu_{\max }=\mathrm{t} / \mathrm{C}_{4} "$ should $\mathrm{read}$ " $\mathrm{dS} / \mathrm{d} \mu_{\max }=$ $-\mathrm{t} / \mathrm{C}_{4} . "$

Page 1454, column 1, lines 30 and 31: “. . the terms $C_{3}$ and $C_{4}$ equal $\mathrm{YS}_{0}+\mathrm{X}_{0}$ and $\mathrm{C}_{3} \mathrm{Y} / \mathrm{X}+$ $\mathrm{C}_{4} / \mathrm{S}$, respectively" should read " $\ldots$ the terms $\mathrm{C}_{3}$ and $\mathrm{C}_{4}$ equal $\mathrm{YS}_{0}+\mathrm{X}_{0}$ and $\mathrm{C}_{1} \mathrm{Y} / \mathrm{X}+$ $\mathrm{C}_{2} / \mathrm{S}$, respectively.'

\section{Predicting 2,4-Dichlorophenoxyacetic Acid Ester Transformation Rates in Periphyton-Dominated Ecosystems}

DAVID L. LEWIS, HEINZ P. KOLLIG, AND TOM L. HALL

U.S. Environmental Protection Agency, Environmental Research Laboratory, Athens, Georgia 30613

Volume 46 , no. 1 , p. 149 , column 2 , lines 1 and 2 : “. . . $k_{1}$ was directly proportional to $k_{A}$, and $k_{A}$ was constant" should read ". . . $k_{1}$ was directly proportional to the ratio of colonized surface area to container volume, and $k_{A}$ was constant." 